\title{
Charles Dickens' Great Expectations as a Bildungsroman Novel
}

\author{
Hayfaa A. Ahmed \\ Instructor/ English Department/ Diyala University/ College o Basic Education \\ *Corresponding Author: Hayfaa A. Ahmed, Instructor, English Department, Diyala University, \\ College o Basic Education
}

Received Date: 08-06-2017

Accepted Date: 16-06-2017

Published Date: 23-06-2017

Charles Dickens is considered the most wellknown writer of the Victorian period. He is born in 1812 at Landport near Portsmouth. His father worked as a simple clerk in a navy pay office. Because his father was imprisoned, he was forced to leave his school and worked in a blacking warehouse in order to help his family. And these two events greatly affected his future as a novelist. Fortunately, his family inherited some money, however, Dickens came back to the school after his father's releasing from prison. Again, Dickens left the school at age of 15 and worked as a law clerk, a reduction reporter in the courts, and also as parliamentary reporter. Subsequently, he started to contribute his stories to newspapers and magazines. Thereafter he became the editor Bentley's Miscellany, and there, he started to publish Oliver Twist in serial between 1837-38 (Cardwell, 2008, 3). It is also the year of Queen Victoria to accession to the throne.

Between 1849-50, Dickens published his preferable child; the semi-autobiographical David Copperfield followed by Bleak House (1852-3), Hard Times (1854), and in 1855-7 Little Dorrit. After his separation with his wife, Catherine Thomson, in 1858, he returned to historical fiction, he wrote A Tale of Two Cities in 1859. Thereafter, he wrote Great Expectations in 1861. His last novel was Our Mutual Friend which was published in 1864-5. His unfinished novel was Edwin Drood. He died in 1870.

Before he started to write Great Expectations, Dickens reread his novel David Copperfield to avoid any similarity between these two works. Eventually he was satisfied that the two personages David and Pip are precisely different (Bloom, 2005, 7).

Major part of Dickens's life is coincidence with Queen Victoria's reign, the early Victorian period which witnessed a massive social change. The immense expression of trade related to the Industrial Revolution in addition to the innovation of railways which was accompanied by political form. And this made middle classes powerful and promoted massive reforms. Dickens acted an active role in encouraging reforms by reviving the conscience of the age by his novels.

At that time not all people red novels, as they were only concerned with middle classes, because it was so expensive until 1830 . Although people were interested in poetry and essays, yet at the same time cheap magazines were founded, these magazines started to publish novels in serialize, and read by all people. As an author and magazine editor, Dickens was the first supporter of this kind of production. Eventually he became the celebrated writer of novel in the English-speaking world. By doing so Dickens is contributed as one from those who lead to literacy rising in the inhabitance from $50 \%$ to $97 \%$ with the end of century (Bloom, 2005, 7). Besides that, novel is the most popular genre in this time because it is easy to read and understand by all people.

The first publishing for Great Expectations was in serial between 1860-61. Then, it issued as a book form in 1861. The original ending of Great Expectations was unlike the one that we read it now. As Sir. Edward Bulwer-Lytton said that "Dicken's original ending might disappoint his Victorian readers, who had come to be expected the virtuous and reformed characters be rewarded with the joy of home and family". And as a response for Bulwer-Lytton's opinion, Dickens changed the novel's ending and made it happy ending (Kriegel, 2010, 520). Dickens worked to make Pip meets Estella in the destructions of Satis House after she becomes a widow, and shifted his last sentence from "I could see the shadow of no parting from her" 
into "I saw no shadow of another parting from her", but also the end is still ambiguous whether Pip and Estella are married or remain single (Schlicke, 1999, 260).

The novel is divided into three parts; the first part is concerning Pip as an orphan has only seven years old, lives and brought up by his harsh sister, she has "hard and heavy hand" (Dickens, 8), and his brother in law Joe Gargery who was so kind with him. Pip was encountered with a convict in the churchyard while he is visiting his parents' tombstones and he asked him to bring food and a file " you bring me tomorrow morning early that file and them wittles. You bring the lot to me, at that old Battery over yonder. You do it and you never dare to say a word or dare to make a sign concerning your having seen such a person as me" (Dickens, 6)

An arrangement meeting is done by uncle Pmblechook between Pip and Miss Havisham to play in her house according to her order. Here he meets Estella, a young and beautiful girl and he falls in love with her. Then Miss Havisham asks Pip to walk with her around the decayed feast from time to time about ten months. Eventually, she rewards him by helping him to be an apprenticeship and becoming a blacksmith with Joe. But his ambition was bigger than this, he wishes to be gentleman for the sake of Estella. Fortunately, Mr. Jaggers, a lawyer tells Pip that a benefactor will help him to be gentleman and he (the benefactor) has left him fortunes. He asks Pip to leave the marshes and go to London to start a new life. Of course, Pip believes that the benefactor is Miss Havisham.

The second part presents Pip's life in London. $\mathrm{He}$ and Herbert (a young gentleman) become friends. In London, Pip falls deeply in debts. Several of events have happened in this part. $\mathrm{He}$ is visited by Joe and he feels embarrassed by him. He also is visited by the convict, Magwitch, who reveals that he is his benefactor and it was a great disappointment for Pip (Clamon, 1994, 6). At first he hates the benefactor and feels shame of him, just to think that he will be gentleman by the help of this criminal, but later his hatred turns into gratitude and humility which is associated with Joe and home.

The last part reveals all the mysteries of the novel. The second convict, Compeyson, who was Magwitch's enemy, is drowned when Pip attempted to help Magwitch to fly. He also discovers that Magwitch is Estellas's father and Molly, Jeggaers' housekeeper is her mother. Pip works as a clerk in Cairo with Herbert. After eleven years, he returns to find Estella near of Satis House and they stayed together (Clamon, 1994, 7).

This paper will present the novel as a Bildungsroman one.

Generally speaking; bildungsroman portrays the protagonist's life through stages starting from the childhood to early maturity "as a growing up and gradual self-discovery in the schoolwithout-walls that is experience." (Schmid, 2004, 3). A bildungsroman novel can be divided into three phases in the protagonist's life; childhood, youth, and maturity. The first phase reflects the hero who oftentimes an orphan grows up with satisfaction of his life, living in the country. By attending school, he/she discovers it is not satisfaction. Because of shortage and lack of choices, the protagonist starts to explore his/her way in life, outside the country and almost is London, particularly this design for Victorian era, when the British Empire becomes at its best political and colonial power with its center with London. Then, the second phase is represented by moving the protagonist from the countryside to the city. Only in this phase, the protagonist begins to get real education. He/she is also "increasingly alienated from his childhood friends and persons of trust and experiences urban life". Moreover, the story includes the glory and humiliating love affairs. Victorian Bildungsroman has a typical theme is the making of a gentleman. Just by reassess his values; he can attend the final phase of maturity. Eventually the hero comes back to his original place to show or determine the degree of his failure and success (Schmid, 2004, 3).

Bildungsroman is a term often applied to novels of education. It is used, firstly, by German, and the best one who imitated is Goethe's Wilhelm Meisters Leurjahre (Wilhelm Meister's Apprenticeship). It becomes famous in England with Carlyle's translation in 1824. The German term Bildungsroman has been adapted in English criticism during the $19^{\text {th }}$ century. In English literature the term is often translated as a novel of youth, of education, of apprenticeship, of adolescence, of initiation, or of the life-novel (Drabble, 2000, 100). Sometimes the novel also can be called fictional autobiography.

Great Expectations is Pip's journey for seeking self-identity, self-improvement and seek to be a gentleman. The novel presents Pip "from humble background to a haven of middle-class respectability offered by his expectations was 
ostensibly a familiar one" (Dennis, 2000, 18). In other words, it is a novel about the desire for wealth and social refinement.

Four expectations that Pip wishes to achieve throughout his journey. The first one, because he lacks real family, so he seeks for both identity and security. The second one, to hide his roughness and commonness he endeavors for education both in respect of knowledge and styles. The third expectation is his concentration with all his power to be a gentleman. His identification for a gentleman is based on social class, prestige, and money. If he succeeds to grasp all these targets, he will win Estella, as he thinks, and this is his fourth expectation. Pip starts to think about these expectations when he understands the meaning of poverty, ignorance, and immorality. Thus his dream is not to be poor, ignorant, and immoral. So Pip, the narrator criticizes his past behaviors as an extremely roughly and seldom giving himself confidence for good deeds, on the contrary, he angrily rebuke himself as bad ones.

as I went along, on all I had seen, and deeply revolving that I was a common laboring boy; that my hands were coarse, that my boots were thick; that I had fallen into a despicable habit of calling knaves Jacks; that I was much more ignorant than I had considered myself last night, and generally that I was in a low-lived bad way (Dickens, 64).

As a child, Pip has good nature, gentle and moral strong. He loves all people around him like Joe and Biddy. He considers them his guidance. Whenever he commit mistake or does a bad thing, he suffers and considers himself guilty. For instance when he is forced to help the convict Magwitch to steal food and file, all the time he feels restless and commit crime and betraying his sister and Joe who he loves him most: " the guilty knowledge that I was going to rob Mrs. Joe- I never thought I was going to rob Joe, for I never thought any of the housekeeping property as his-united to the necessity of always keeping one hand on my bread-andbutter" (Dickens, 13).

But at the same time Pip also reflects his compassion and kindness for Magwitch when he gives him the food. Pitying his desolation, and watching him as he gradually settled down upon the pie, I made bold to say, I'm glad you enjoy it.
Do you speak? I said I was glad you enjoyed it (Dickens, 19).

His life in the marsh is very simple and humble and he is content with this kind of life especially with Joe and with his job as apprentice to him: "I always treated him [Joe] as a larger species of child, and as no more than my equal" (Dickens, 9). He has a good relationship with Biddy, his classmate, and they attend school together. They are also good friends "Yes Biddy, I observed, when I had done turning it over, 'you were my first teacher, and that at a time when we little thought of ever being together like this, in this kitchen' (Dickens, 124).

The turning point in Pip's life starts when he visits the Satis House of Miss Havisham and particularly when he meets Estella, a young and beautiful girl. He starts to think about his situation and his status especially when she calls him as "common laboring boy" (Dickens, 58). Before he meets Estella, Pip had been unconscious about class distinction, and he was not care that he belonged to the common class. Also when they are playing card, she scorns his hands because they were rough, she says: "And what coarse hands he has. And what thick boots!" (Dickens, 59). Thereafter, Pip lives in confusion and his mind is unstable; he finds himself admiring her beauty and can't prevent himself from thinking about her: "I'm never see her again though she is so pretty? I'm not sure that I shouldn't like to see her again, but I should like to go home now" (Dickens, 60). He also hurts by her scorn, and all the time she insults and tortures him about his lower social class status. Especially when she offers him food, she treats him like a dog: "and gave me a bread and meat without looking at me, as insolently as if I were a $\operatorname{dog}$ in disgrace. I was so humiliated, hurt, spurned, offended, angry, sorry - I can't hit upon the right name for the smart - God knows what its name was - that tears started to my eyes." (Dickens, 61). Her behavior and her speech with him were like a blow upon his head, and he begins to think that he must be a gentleman to be like her and to win her heart. Through the conversation between him and Biddy, Pip told her that he is unsatisfied with his life and he wants to change it "well then, understand once for all that I never shall or can be comfortable or anything but miserable-there, Biddy, unless I can lead a very different sort of life from the life I lead now" (Dickens, 125). We can say that Estella is considered the fire lighted Pip's heart to climb to the social class in order to 
be a gentleman "The beautiful young lady at Miss Havisham's, and she's more beautiful than anybody ever was, and I admire her dreadfully, and I want to be a gentleman on her account" (Dickens, 126). Meanwhile, Mr. Jaggers, a lawyer, coming from London and visiting Pip's home to inform him and Joe that a benefactor will support Pip financially and raising him to be a gentleman, therefore, he must travel to London to take lessons about how to be a gentleman: "I am instructed to communicate to him, said Mr. Jaggers, throwing his finger at me...Further, that he be immediately removed from his present sphere of life and from this place, and brought up as a gentleman- in a word, as a young fellow of great expectations." (Dickens, 135).

Pip becomes extremely happy, as if he finds Aladdin Magic Lamp which will fulfill all his expectations. He will be a gentleman as he wishes and will rise to the social class to be like Estella, and then, he will be deserved to win her heart. But until now he doesn't know who is the benefactor, though for the first time he thought that Miss Havisham is his benefactor, and in this case it will be easy to marry Estella, and "the world lay spread before me" as Pip said (Dickens, 157).

In London, Pip starts his lessons with Mr. Matthew Pocket, Herbert's father. In addition, some important instructions as a gentleman will be taught with Mr. Herbert Pocket (a young gentleman). Later, they become close friends. From time to time, Herbert instructs Pip on convenient London table styles. Pip himself asks Herbert to help him to the manners and manners of London, he tells him: "I further mentioned that as I had been brought up a blacksmith in a country place, and knew very little of the ways of politeness" (Dickens, 176). Pip follows any advice or instruction saying by Herbert, he knows that Herbert wants to help him, thus, he never feels that Herbert tries to insult him, on the contrary, all the time, Pip thanks him when the later corrects any mistake.

By time, Pip has undergone a lot of changes in his appearance; in the past, he was an ordinary person and the goal of criticism and scorns by Estella, now he believes that he has improved a gentlemanly behavior and etiquette. But on the other side, he starts to feel shameful and embarrassed of his past life in the marsh with Joe and Biddy. Overtime, when he knows that Joe will come to London and want to see him, Pip doesn't express his happiness with his best friend in the marsh; instead, a growing discomfort seizes him and wishes that Joe won't come to London when Pip now lives a sophisticated life. He thinks if he could offer money for him and avoiding his visit "Not with pleasure, though I was bound to him by so many ties;" (Dichens, 215), they share a relationship based on love and trust, like father and son or two brothers. "no; with considerable disturbance, some mortification, and a keen sense of incongruity. If I could have kept him away by paying money, I certainly would have paid money" (Dickens, 215). When Joe arrives, Pip treats him arrogantly; he appears so cold with him. Joe immediately recognizes that Pip doesn't wish to see him, thus, Joe decides not to stay the night with him in the same room. Likewise Pip through his visiting to his town he doesn't stay down with Joe, instead he takes a room at in inn. As he believes, if he stays at the forge, his new style would be hurt. By doing so, Pip hurts and betrays his childhood friends Joe and Biddy and his original morality "It was too early yet to go to Miss Havisham's, so I loitered into the country of Miss Havisham's side of town-which was not Joe's side; I could go there to-morrow-thinking about my patroness, and painting brilliant pictures of her plans for me" (Dicken, 229).

Pip begins to grow into a false man when he becomes in contact with money and the life of upper class. Moreover, his search for selfimprovement and to be a gentleman, in addition to his dream to marry Estella, all these expectations lead to create another Pip. And just now he knows what an unpleasant man he has become. He has avoided and betrayed all people who care for and love him:

As I grown accustomed to my expectations, I had insensibly begun to notice their effect upon myself and those around me. Their influence on my own character, I disguised from my recognition as much as possible, but I knew very well that it was not all good. I lived in a state of chronic uneasiness respecting my behavior to Joe. My conscience was not by any means comfortable about Biddy (Dickens, 268).

Pip's great disappointment is when he knows the real benefactor behind his fortune. It is Magwitch, the convict whom he helped when he was a child in the marsh. His knowing the truth that it is not Miss Havisham is his benefactor as he thought for a long time. Now he entirely 
realizes that the distance between him and Estella becomes bigger and bigger and immediately all his dreams are shuttered. It is ironically to believe that the person who supports him to be a fortune and gentleman is a criminal and convict "All the truth of my position came flashing on me; and its disappointments, dangers, disgraces, consequences of all kinds, rushed in in such a multitude that I was borne down by them and had to struggle for every breath I drew" (Dickens, 314).

Throughout Pip's journey for self-improvement, Dickens reveals the truth of social system of Victorian period starting from the criminal Magwitch to the simple and poor villagers of the marshes Joe and Biddy, passing by the middle class Pumblechook and upper class as $\mathrm{Mr}$. Jaggers to the rich one as Miss Havisham. Dickens presents the contrast between lower class and upper class; between Magwitch, the convict, the criminal and Miss Havisham an educated and rich woman. Though Magwitch is dirty, sloppy and rude, eating "in a ravenous way that was very disagreeable, and all his actions were uncuth, noisy, and greedy" (Dickens, 327)unlike any other wealthy character in the novel, he is self-made man. He collects his fortune through hard work. Eventually all his money is delivered to Pip. He thinks of Pip as his son or more as he says "I 'm your second father. You're my son - more to me nor any son" (Dickens, 315). But according to social class he is not considered as a gentleman. Magwitch thinks that gentlemanliness can be bought. Thus he tells Pip "If I ain't a gentleman, not yet ain't got no learning, I'm the owner of such. All you owns stock and land; which on you owns a brought-up London gentleman?" ( Dickens, 316-17). The term of gentleman is connected with the appearing of middle class after the Industrial Revolution. The gentleman of middle class has different criteria. To be a gentleman, one must be wealthy, has a fine clothes, and pompous behavior rather than virtue and faultless manner. (Berberich, 2016, 35). Joe represents the laborer class, the most one who loves Pip from the first time. He asked his wife, Mrs. Joe to bring him to live with them "I said to her, And bring the poor little child, God bless the poor little child". He also cared him when Pip was ill in London. Moreover, he pays off all his debts. Though he is not educated and never becomes what Pip wishes as a gentleman. Nevertheless he doesn't need to, he is already gentleman more than most of upper class. While uncle Pumblechook represents middle glass, he is a greedy and used to cheat Pip by adding water to his milk. He told everybody that he had a hand in helping pip to his fortune. Miss Havisham and Estella represent upper class, wealthy and well educated, yet they treat others and specifically Pip harshly and insulted him. Moreover they are heartless and their purpose is to destroy men's hearts. Miss Havisham adopted Estella, and nourished her hatred, to break men's hearts, to destroy them, to exploit her beauty in torturing her admirers for the sake of revenge. Miss Havisham uses Estella as a tool. Eventually she destroys Estella herself: "I am what you have made me. Take all the praise, take all the blame, take all the success, take all the failure, in short, take me" (Dickens, 299). Mr. Jaggers, the lawyer, also represents upper class and he must represent the law of London. He always wins the cases and he also getting the criminals off. Harold Bloom in his book Bloom's Guides, describes him as "an intimidating and prominent (Bloom, 2005, 16). He is so harsh and merciless with his clients as we see when Mike, a client, asks him to help his daughter who had been taken up on suspicion of shoplifting, Jagger dismissed him out though the man's eyes was full of tears "Now, look here my man ...pointing to the door. Get out of this office. I'll have no feelings here. Get out" (Dickens, 410). He already has dirty business of being "Old Bailey", for this reason, he used to wash his hands with perfumed soap.

Consequently among this class we see the laboring poor who still keep their higher tone than those of the upper class. Pip understands that only good deeds can bring respect, not wealth. At the end of the novel, Pip gets the title of a real gentleman, as I think, only when he helps Magwitch and nurses him, also by helping Herbert secretly (Alexander, 2005, 576). He said to himself "I did really cry in good earnest when I went to bed, to think that my expectations had done some good to somebody" (Dickens, 295). The lesson that Pip learned that one's social status is associated with one's personality and character not with the class. At the end of his journey, Pip rejects the social class and comes back to his original place, the marshes where he spent his childhood. Undoubtedly, he learns a lot from this experience (Dennis, 2000, 18).

Actually the moving of Pip from the small and isolated village to London seeking to be a gentleman represents the outflow of middle class, after the industrial Revolution to show the 
emphasis of material over ancestral name. As we know that Pip has no real ancestral name. His name is mixture of his given name Philip with his family name Pirrip. The novel tries to make balance between social class and morality. We can notice that social system takes a large space in this novel. Dickens tells us through pip's realization that both; money and class have no any importance while affection, loyalty, and morality are more important for human being.

We should put in our mind that Pip is both; Pip, the protagonist of the novel, immature, romantic ideals with deep desire to improve himself and attain any advancement whether educational, moral or social, and Pip, the narrator for all the events with perspective and maturity. Dickens presents Pip as two characters, as we hear the story, we hear a mature person telling us the events about Pip as a child with his simple language and simple expression. For instance when Pip depicts his feeling of inefficiency and weakness about himself and his family when he spends the day at Satis House for the first time: "I thought how Joe and my sister were then sitting in the kitchen, and how I had come up to bed from the kitchen, and how Miss Havisham and Estella never sat in a kitchen, but were far above the level of such common doings" (Dickens, 70). Later Pip comments on the day from his present perspective, now he is mature and referring to his past, he is no longer young with innocent, simple and narrow view of life.

That was a memorable day to me, for it made great changes in me. But, it is the same with any life. Imagine one selected day struck out of it, and think how different its course would have been. Pause you who read this, and think for a moment of the long chain of iron or gold, of thorns or flowers, that would never have bound you, but for the formation of the first link on one memorable day (Dickens, 71).

Of course, like this technique, enables the author to give his commentaries about past events (The Victorian Web, 2016).

Throughout Pip's story of growth, Dickens examines the period of temptation of young as Bernard N. Schilling asserts in his book The Rain of Years that "Dickens accuses the time of encouraging illusion the young and then frustrating their hopes of inspiring excessive ambition and then requiring calculated acts of cruelty to fulfill that ambition, of depriving youth to its grace, vitiating its generous sentiment. Youth is lead from a wholesome past into a corrupt future (64). In Great Expectations, Dickens succeeded to establish themes of money and social class to make Pip learns a great lesson from his experience. Pip discovers at the end of the novel that affection, loyalty, and conscience are more important than social advancement, money and class. By exploring his great expectations he discovers new things more important and more valuable than what he has sought.

\section{REFERENCES}

[1] Alexander, M. Lynn edt. John Halfax, Gentleman. Broadview editions, 2005.

[2] Bloom, Harold. Charles Dickens: Great Expectations. Charles house publishers, 2005.

[3] Cardwell, Margaret edt. Charles Dickens: Great Expectations. Oxford University Press, 2008.

[4] Clamon, Judy. Charles Dickens: Great Expectations. United State of American, 1994.

[5] Dennis, Barbara. The Victorian Novel. Cambridge University Press, 2000.

[6] Drabble, Margaret. The Oxford Companion to English Literature. Oxford University Press, 2000.

[7] Kriegel, Jill edt. Charles Dickens: Great Expectations. Ignatius Press: San Francisco, 2010.

[8] Schilling, N. Bernard. The Rain of Years: Great Expectations and the World of Dickens. University of Rochester Press, 2001.

[9] Schlicke, Paul. Oxford Reader's Campanion to Dickens. New York: n Oxford University Press, 1999.

[10] Schmi, Matias. Great Expectations as a Bildungsroman. University ErlangenMurnbery, 2004.

[11] Victorian Web. < http://www.victorianweb.org / >. Web. Dec. 5, 2016.

\section{AUTHOR'S BIOGRAPHY}

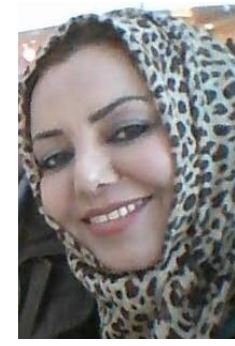
I am Hayfaa Abdulkhaleq Ahmed. I am Instructor at Diyala University/ College of Basic Education/ Iraq. I was asst. director of English Department. I participated into two conferences in my country through two papers:

1. The knowledge economy and its given in Higher Education 
Charles Dickens' Great Expectations as a Bildungsroman Novel

2. Visions of the Future for Sustainable development in Iraq

Also I published two researches:

1. A Study of Technique in Selected plays by Bernard Shaw

2. Walt Whitman: The Representative of American People

Now, I am a student of Ph.D. at Atilim

University in Turkey

Citation: Hayfaa A.Ahmed. "Charles Dickens' Great Expectations as a Bildungsroman Novel". International Journal of Research in Humanities and Social Studies, vol 4, no. 5, 2017, pp. 1-7.

Copyright: (C) 2017 Hayfaa A., Ahmed. This is an open-access article distributed under the terms of the Creative Commons Attribution License, which permits unrestricted use, distribution, and reproduction in any medium, provided the original author and source are credited. 